\title{
Antagonistic Effect of the Endophytic Bacteria and Against some Phytopathogens
}

\author{
Hend M.M. Selim*, Nafisa M. Gomaa and A.M.M. Essa \\ Department of Botany, Faculty of Science, Fayoum University, \\ Egypt.
}

\begin{abstract}
4 NDOPHYTIC bacteria have received a great attention because of their intimate and non-detrimental association with plants. They release an array of bioactive compounds that play important role in the biological control of various phytopathogens. A variety of endophytic bacteria was isolated from a range of plants gathered from Fayoum Government, Egypt. The antagonistic potentiality of the bacterial isolates was evaluated against a number of phytopathogens. A sharp antifungal activity was recorded with isolate H8 against Rhizoctonia solani and Pythium ultimum while elevated antagonistic potentiality was evidenced with isolate H18 against Erwinia carotovora and Rhizoctonia solani. Simultaneously, the isolate H40 demonstrated remarkable inhibitory influence against Erwinia carotovora and Fusarium solani. Using 16S ribosomal DNA technique, the bacterial isolates were identified as Stenotrophomonas maltophilia, Bacillus subtilis, and Pseudomonas aeruginosa. In conclusion, the bacterial strains S. maltophilia $(\mathrm{H} 8)$, B. subtilis $(\mathrm{H} 18)$ and P. aeruginosa $(\mathrm{H} 40)$ could be used as biological agents against wide range of phytopathogens.
\end{abstract}

Keywords: Antagonism, Stenotrophomonas maltophilia , Bacillus subtilis, Pseudomonas aeruginosa, Phytopathogens.

Plant pathogenic microorganisms represent a great danger to crop production and ecosystem (Sabuquillo et al., 2006). With respect to phytopathogens, many effective pesticides are available, but they will not be reliable as a long-term solution because of concerns about exposure risks and residue persistence. Moreover, tolerance in the target pathogen may be developed as a result of frequent application of pesticides.

Endophytes are microorganisms that live inside living tissues of plants. In most cases, the microbial relationship with the host plant is symbiotic or mutualistic with no visible damage or morphological changes on their hosts (Schulz and Boyle, 2006). Because endophytes live in a steady environment inside the plant, they have more antagonistic potentiality than microorganisms isolated from rhizosphere, plant surface, or soil (Andrews, 1992).

As an important group of endophytes, endophytic bacteria have received a wide attention on their bioactivities including antibiotics production, biological

*Corresponding author : e-mail: doc_hend@yahoo.com 
control of plant diseases, plant growth stimulation and nitrogen fixation (Qiao et al. 2006 and He et al., 2010). Furthermore, endophytic microorganisms have a vast role in the release of insecticidal compounds (Guo et al., 2000 and Shi et al., 2013).

The application of microorganisms and their bioactive compounds as biocontrol agents has become a promising approach to manage phytopathogenic microorganisms. Many beneficial microbes, including antagonistic endophytic bacteria, applied as treatments with different formulation provide privileges for crop production and protection against soil-borne pathogens. One of the advantages of using endophytes as biocontrol agents is that they exist in the same place where the plant pathogen survive that provide competition sufficient to inhibit many plant diseases especially vascular diseases. Another advantage is that they do not cause environmental contamination (M Bhattacharjee et al., 2014).

A wide array of endophytic bacteria have been isolated from a variety of plants (Rosenblueth and Martínez-Romero 2006; Hameed et al., 2015). Endophytic bacteria have been recorded to demonstrate an inhibitory effect against many plant pathogenic fungi such as Verticillium longisporum, Rhizoctonia solani, Fusarium oxyporum and Phythium ultimum in balloon flower; Rhizoctonia solani and Fusarium oxyporum in cotton; Sclerotium rolfsii in beans; Verticillium dahliae, Verticillium alboatrum and Rhizoctonia solani in potato and Rhizoctonia solani in ginseng (Berg et al., 2005 and Cho et al., 2007). In addition, Amaresan et al. (2015) highlighted the antagonistic influence of some endophytic bacteria isolated from chilli plants (Capsicum annuum) against the phytopathogens Sclerotium rolfsii, Fusarium oxyporum, Phythium sp. and Colletotrichum capsici

Moreover, endophytic bacteria demonstrated great antibacterial potentiality against many plant pathogens such as Paenibacillus polymyxa, Bacilllus sp. and Pseudomonas poae (Seo, 2010); Xanthomonas oryzae and Burkholderia glumae (Chung et al., 2015). Endophytic microorganisms offer great advantages to host plant via producing wide variety of bioactive molecules that participate in plant protection (Chakraborty et al., 2010 and Dutta et al., 2014). The objectives of this study were: (1) to examine the population structures of endophytic bacteria of some crop plants; and (2) to investigate the antagonistic activities of the endophytic isolates against some phytopathogenic fungi and bacteria.

\section{Materials and Methods}

\section{Isolation of endophytic bacteria}

Various crop plants were gathered from diverged sites in Fayoum Governorate, Egypt. Plants were congregated in plastic bags and taken to the laboratory instantly. Healthy plants were selected for the isolation of the endophytic bacteria according to Suryanarayanan et al. (2005). Plants were washed with distilled water to get rid of adhered soil particles. Two or three

Egypt. J. Bot., 56, No. 3 (2016) 
$10 \mathrm{~mm} \times 10 \mathrm{~mm}$ segments were cut randomly from stems, leaves, and roots of each plant. Segments were separated, and subjected to sequential immersion of each plant part in $95 \%(\mathrm{v} / \mathrm{v})$ ethanol for $2 \mathrm{~min}$, sodium hypochlorite for $90 \mathrm{sec}$ and $95 \%$ ethanol for $30 \mathrm{sec}$ followed by three rinses in sterilized distilled water. Plant parts were dried using sterilized paper towels and placed on nutrient agar (NA) medium. Plates were incubated at $25^{\circ} \mathrm{C}$ for 3-7 days. The emerging bacterial colonies from the plant segments were picked out, streaked on nutrient agar plates and incubated at $28^{\circ} \mathrm{C}$ for $48 \mathrm{hr}$ to get the pure culture. The purified bacterial isolates were cultivated in $5 \mathrm{~mL}$ of nutrient broth with constant shaking $(100 \mathrm{rpm})$ at $28^{\circ} \mathrm{C}$ for $48 \mathrm{hr}$. The isolated bacteria, cultures were suspended in $20 \%$ glycerol solution and were kept at $-80^{\circ} \mathrm{C}$.

\section{Phytopathogens}

The antimicrobial activity of the isolated endophytic bacteria was carried out against the following plant pathogens Fusarium solani, Fusarium oxysporum, Pythium ultimum, Sclerotium rolfsii, Aspergillus flavus, Aspergillus niger, Rhizoctonia solani, Alternaria solani, Erwinia carotovora I and Erwinia carotovora II. These strains were afforded by the City of Science and Technology, Cairo, Egypt. The fungal strains were cultured on potato dextrose agar (PDA) meanwhile bacterial strains were cultured on nutrient agar (NA).

\section{Antimicrobial activity of the endophytic bacterial isolates}

At the beginning, the antagonistic activity of the endophytic isolates were evaluated against $F$. solani that cause damping-off and root rot diseases to many vegetable and crop plants in Fayoum, Egypt. The bacterial isolates that demonstrated clear antagonistic activity against $F$. solani were further evaluated against the rest of the phytopathogens. The antimicrobial potentiality was assayed according to Lin et al. (2009). For antifungal assay, the endophytic bacteria were grown on nutrient agarplates at $30^{\circ} \mathrm{C}$ for $24 \mathrm{hr} .100 \mu \mathrm{L}$ of spore suspension $(200 \mathrm{cell} / \mu \mathrm{L})$ from each fungus was spread on PDA plates. At equal places of PDA plates, nutrient agar discs of the endophytic bacteria were placed. Triplicate dual-inoculated plates, with the fungus alone as a control were incubated at $28^{\circ} \mathrm{C}$ for 7 days. Regarding antibacterial assay, one hundred microliter of the bacterial culture $\left(10^{8} \mathrm{CFU} / \mathrm{mL}\right)$ was spread on nutrient agar plates. Then the inoculated plates were kept at $28^{\circ} \mathrm{C}$ for $48 \mathrm{hr}$ and diameters of inhibition zones were measured in millimeter.

\section{Morphological characterization of the bacterial isolates}

Stock cultures were plated out on nutrient agar plates and single colonies were picked and sub-cultured. Under stereomicroscope, colony morphologies were examined. Gram and endospore staining were carried out according to Prescott et al. (1996) while negative stain was used to stain bacterial capsule. At the same time, semisolid medium was used to examine the motility of the bacterial isolates (Soutourina et al., 2001). 


\section{Biochemical characterization of bacterial isolates}

The biochemical characters of the bacterial isolates were investigated using API 20E panel systems according to the manufacturer's instructions (BioMerieux, France). In order to obtain single colonies for each bacterial isolate, stock cultures were streaked onto nutrient agar. $200 \mu \mathrm{L}$ bacterial suspension of each isolate was transferred into the starting well of the panels. In order to prevent contamination, wells were filled with mineral oil and then were incubated at $30 \circ \mathrm{C}$ for $24-48 \mathrm{hr}$. The results of the tests were evaluated according to the computer-based program 'IdBact v. 1.1, G. Kronvall, with Matrix for API from BioMerieux, France.

\section{Identification of the bacterial isolates}

In order to identify the isolated bacteria, genomic DNA was extracted using standard bacterial procedures (Essa, 2012). Two primers were used to amplify the 16S rDNA gene; (F1) AGAGTTTGATCCTGGCTCAG and (R1) GGTTACCTTGTTAC GACTT. PCR mixture was prepared as the following; $10 \mu \mathrm{L}$ (10x) PCR buffer, $3 \mu \mathrm{L}(50 \mathrm{mM}) \mathrm{MgCl}_{2}, 1 \mu \mathrm{L}(20$ pmole $/ \mu \mathrm{L})$ of each primer, 1 $\mu \mathrm{L}(10 \mathrm{mM}) \mathrm{dNTPs}$ mixture, $0.5 \mu \mathrm{L}(2.5 \mathrm{U})$ Taq DNA polymerase, $2 \mu \mathrm{L}$ total DNA extract and the volume is completed to $100 \mu \mathrm{L}$ by $\mathrm{SD} \mathrm{H}_{2} \mathrm{O}$. Thirty five cycles of PCR were performed under the following conditions: $94^{\circ} \mathrm{C}$ for $40 \mathrm{sec}$ (denaturation step), $55^{\circ} \mathrm{C}$ for one min (annealing step), $72^{\circ} \mathrm{C}$ for 2 min (extension step) and $72^{\circ} \mathrm{C}$ for $10 \mathrm{~min}$ (final extension step). $10 \mu \mathrm{L}$ aliquots of the PCR products were mixed with $2 \mu \mathrm{L}$ of DNA loading buffer and analyzed by electrophoresis $(15 \mathrm{~V} / \mathrm{cm}, 60 \mathrm{~min})$ on $0.7 \%$ horizontal agarose gel in TBE buffer containing $0.5 \mu \mathrm{g} / \mathrm{mL}$ ethidium bromide, then visualized on an UV transilluminator. Sequencing of the amplified fragments were sequenced at GATC Biotech, Constance, Germany and DNA sequences were aligned at NCBI DataBase (www.ncbi.nlm.nlh.gov).

\section{Statistical analysis}

The data presented here are the mean value of three replicates. Standard errors were determined using MS Excel 2007.

\section{Results}

Isolation of endophytes and their antimicrobial activity

About fifty two bacterial strains were isolated from various crop plants where 23 isolates from roots, 15 isolates from stems and 14 isolates from leaves (Table 1). Antifungal activities of the bacterial isolates were assayed firstly against $F$. solani. 
TABLE 1. Isolation sources of the endophytic bacteria.

\begin{tabular}{|c|c|c|c|c|c|}
\hline Isolates & Source & Tissue & Isolates & Source & Tissue \\
\hline $\mathrm{H} 1$ & Capsicum аппиит & Root & H31 & Raphanus sativus & Leaf \\
\hline $\mathrm{H} 2$ & Raphanus sativus & Leaf & $\mathrm{H} 32$ & Pisum sativum & Stem \\
\hline $\mathrm{H} 3$ & Cucumis sativus & Root & H33 & Sesamum indicum & Stem \\
\hline $\mathrm{H} 4$ & Allium cepa & Leaf & $\mathrm{H} 34$ & Cucumis sativus & Root \\
\hline H5 & Sesamum indicum & Stem & H35 & Cucumis sativus & Root \\
\hline H6 & Cucumis sativus & Root & H36 & Cucumis sativus & Stem \\
\hline $\mathrm{H} 7$ & Brassica oleracea & Stem & H37 & Cucumis sativus & Stem \\
\hline $\mathrm{H} 8$ & Brassica oleracea & Root & H38 & Cucumis sativus & Leaf \\
\hline H9 & Cucumis sativus & Leaf & H39 & Cucumis sativus & Root \\
\hline $\mathrm{H} 10$ & Cucumis sativus & Root & $\mathrm{H} 40$ & Pisum sativum & Root \\
\hline H11 & Pisum sativum & Stem & $\mathrm{H} 41$ & Cucumis sativus & Leaf \\
\hline H12 & Raphanus sativus & Leaf & $\mathrm{H} 42$ & Sesamum indicum & Stem \\
\hline H13 & Brassica oleracea & Leaf & $\mathrm{H} 43$ & Pisum sativum & Root \\
\hline H14 & Pisum sativum & Leaf & $\mathrm{H} 44$ & Brassica oleracea & Leaf \\
\hline $\mathrm{H} 15$ & Pisum sativum & Root & $\mathrm{H} 45$ & Cucumis sativus & Root \\
\hline H16 & Solanumm elongena & Root & $\mathrm{H} 46$ & Helianthus annuus & Root \\
\hline $\mathrm{H} 17$ & Pisum sativum & Root & $\mathrm{H} 47$ & Capsicum annuum & Stem \\
\hline H18 & Capsicum annuum & Stem & $\mathrm{H} 48$ & Cucumis sativus & Root \\
\hline H19 & Cucumis sativus & Leaf & $\mathrm{H} 49$ & Sesamum indicum & Stem \\
\hline $\mathrm{H} 20$ & Solanumm elongena & Root & H50 & Cucumis sativus & Leaf \\
\hline $\mathrm{H} 21$ & Sesamum indicum & Root & H51 & Cucumis sativus & Stem \\
\hline $\mathrm{H} 22$ & Brassica oleracea & Root & H52 & Allium sativum & Leaf \\
\hline $\mathrm{H} 23$ & Pisum sativum & Leaf & & & \\
\hline $\mathrm{H} 24$ & Helianthus annuus & Root & & & \\
\hline $\mathrm{H} 25$ & Helianthus annuus & Stem & & & \\
\hline $\mathrm{H} 26$ & Raphanus sativus & Stem & & & \\
\hline $\mathrm{H} 27$ & Capsicum annuum & Root & & & \\
\hline $\mathrm{H} 28$ & Raphanus sativus & Leaf & & & \\
\hline $\mathrm{H} 29$ & Sesamum indicum & Root & & & \\
\hline H30 & Brassica oleracea & Root & & & \\
\hline
\end{tabular}

According to the obtained results, the inhibitory effect of the screened isolates was classified into three groups: low, medium or strong. The gained results (Table 2) demonstrated that the maximum antifungal activity against $F$. solani was recorded by strains H8 $(29 \mathrm{~mm}), \mathrm{H} 18(37 \mathrm{~mm}), \mathrm{H} 40(41 \mathrm{~mm})$ that were isolated from Brassica oleraces, Capsicum sativum and Pisum sativum, respectively. Moreover, the antimicrobial activity of these isolates was further assayed against some selected phytopathogens. The bacterial isolates demonstrated a wide-spectrum antimicrobial activity against the various phytopathogens as shown in Fig.1. 


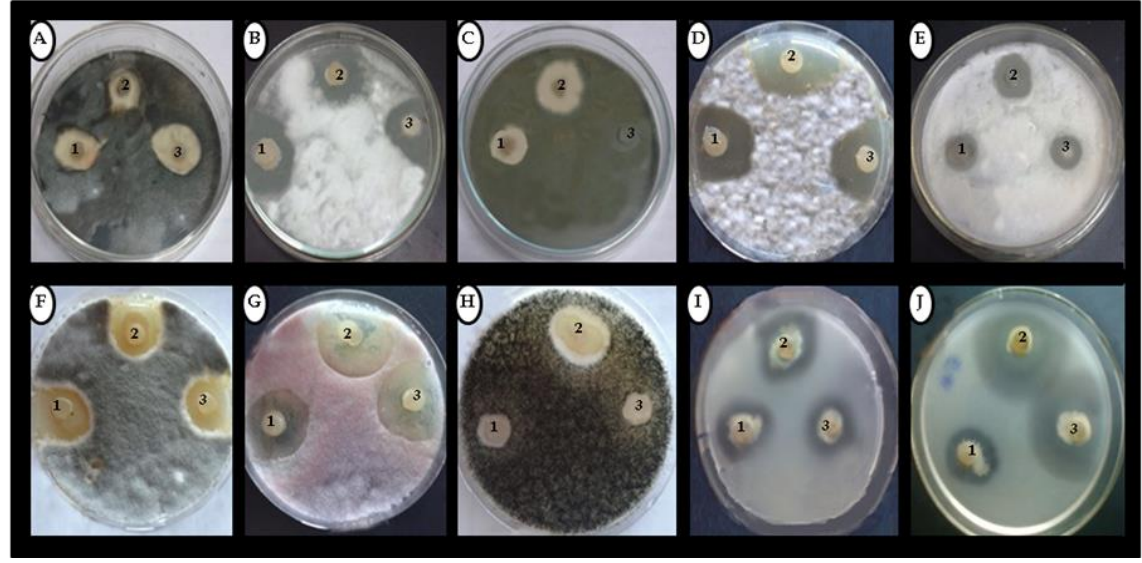

Fig. 1. Antagonistic activity of the endophytic bacterial isolates H8 (1), H40 (2) and H18 (3) against some phytopathogens; Sclerotium rolfsii (A), Pythium ultimum (B), Aspergillus flavus (C), Rhizoctonia solani (D), Fusarium solani (E), Fusarium oxysporum (F), Aspergillus niger (G), Erwinia carotovora II (I) and Erwinia carotovora $\mathbf{I}(\mathbf{J})$.

TABLE 2. Antimicrobial activity of selected endophytic isolates against various phytopathogens. Inhibition zones are measured by millimeter and data are the means of three replication \pm standard errors.

\begin{tabular}{|lccc|}
\hline \multirow{2}{*}{\multicolumn{1}{c}{ Phytopathogen }} & \multicolumn{2}{c|}{ Inhibition Zone diameters (mm) } \\
\cline { 2 - 4 } & $\begin{array}{c}\text { P. aeruginosa } \\
\text { (H40) }\end{array}$ & $\begin{array}{c}\text { B. subtilis } \\
\text { (H18) }\end{array}$ & $\begin{array}{c}\text { S. maltophilia } \\
\text { (H8) }\end{array}$ \\
\hline Fusarium solani & $41 \pm 6$ & $37 \pm 3$ & $29 \pm 3$ \\
Fusarium oxysporum & $23 \pm 3$ & $15 \pm 1$ & $17 \pm 3$ \\
Pythium ultimum & $35 \pm 4$ & $27 \pm 3$ & $39 \pm 4$ \\
Sclerotium rolfsii & $19 \pm 3$ & $29 \pm 5$ & $25 \pm 1$ \\
Aspergillus flavus & $15 \pm 2$ & $19 \pm 2$ & 0.0 \\
Aspergillus niger & $19 \pm 5$ & $15 \pm 4$ & $12 \pm 6$ \\
Rhizoctonia solani & $35 \pm 2$ & $39 \pm 3$ & $43 \pm 3$ \\
Alternaria solani & $21 \pm 4$ & $29 \pm 6$ & $25 \pm 5$ \\
Erwinia carotovora I & $49 \pm 6$ & $45 \pm 3$ & $25 \pm 3$ \\
Erwinia carotovora II & $37 \pm 3$ & $25 \pm 1$ & $21 \pm 2$ \\
\hline
\end{tabular}

Phytopathogens growth was suppressed by the endophytic isolates at different levels. Clear zones of 35, 39 and $43 \mathrm{~mm}$ were recorded by bacterial isolates $\mathrm{H} 40, \mathrm{H} 18, \mathrm{H} 8$ against $R$. solani. Moreover, strain $\mathrm{H} 40$ demonstrated a significant antibacterial activity against Erwinia carotovora I (49 $\mathrm{mm})$ and

Egypt. J. Bot., 56, No. 3 (2016) 
Erwinia carotovora II $(37 \mathrm{~mm})$ meanwhile strain $\mathrm{H} 18$ recorded $45 \mathrm{~mm}$ clear zone against Erwinia carotovora $\mathrm{I}$.

Similarly, clear antifungal potentiality was reported by bacterial isolate $\mathrm{H} 40$ $(35 \mathrm{~mm})$ and isolate $\mathrm{H} 8(39 \mathrm{~mm})$ against $P$. ultimum. In the main time, a marked inhibition of S. rolfsii and A. solani was reported with isolate H18. The three endophytic strains (H40, H18 and H8) demonstrated antimicrobial activity with variable extent against the rest of the phytopathogens as shown in Table 2.

\section{Characterization of the bacterial isolates}

A variety of morphological and biochemical assays were carried out to have a comprehensive view on the phenotypic characteristics of the bacterial isolates as shown in Table 3. The obtained results showed that bacterial isolate (H40) was Gram-negative motile rods. This isolate demonstrated positive results with arginine dihydrolase, tryptophan deaminase, gelatinase, catalase, oxidase and nitrate reductase tests. Simultaneously, H40 demonstrated an aptitude to utilize arabinose and citrate as carbon source. The bacterial isolate H18 was Grampositive motile spore producing rods. This strain demonstrated positive results with $\beta$-galactosidase, tryptophan deaminase, gelatinase, catalase, oxidase and nitrate reductase and acetoin production tests. In the interim, H18 isolate highlighted the potentiality to exploit various sources of carbon such as sucrose, mannitol, inositol, sorbitol, rhamnose, melibiose and amygdalin. Moreover, isolate H8 was Gram-negative motile non-spore forming rods. This strain demonstrated positive results in $\beta$-galactosidase, arginine dihydrolase, orenthine decarbolase, tryptophan deaminase, gelatinase, catalase, oxidase, lipase, nitrate reductase and acetoin production tests. At the same time, the endophytic isolate H8 showed the ability to utilize different carbon sources such as sucrose, manitol, sorbitol, rhamnose, melibiose, amygdalin, arabinose, and citrate. Meanwhile, the three bacterial isolates recorded negative results in urease, amylase, lysine decarboxylase, $\mathrm{H}_{2} \mathrm{~S}$ production, and indole production tests.

\section{Molecular identification of the bacterial isolates}

Beside the phenotypic characteristics of the endophytic isolates, 16S rDNA gene sequencing was used for the molecular identification of the bacterial isolates at higher level. The obtained $16 \mathrm{~S}$ rDNA sequences were aligned with the corresponding sequences of GenBank using Blast program. The bacterial isolates H40, H18 and H8 were identified as Pseudomonas aeruginosa with maximum homology of 99\%, Bacillus subtilis with maximum homology $99 \%$ and Stenotrophomonas maltophilia with $99 \%$ maximum homology, respectively. The $16 \mathrm{~S}$ rDNA gene sequences of the bacterial strains were deposited in National Center for Biotechnology Information (http://www.ncbi.nlm.nih.gov) under accession numbers KF407991 for Stenotrophomonas maltophilia H8, KF407989 for Bacillus subtilis $\mathrm{H} 18$ and KF407990 for Pseudomonas aeruginosa H40 (Fig.2). 
TABLE 3. Morphological and biochemical characterization of the endophytic bacterial isolates.

\begin{tabular}{|c|c|c|c|c|c|c|c|}
\hline \multirow{2}{*}{ Reaction } & \multicolumn{3}{|c|}{ Bacterial isolate } & \multirow[b]{2}{*}{ Reaction } & \multicolumn{3}{|c|}{ Bacterial isolate } \\
\hline & H40 & H18 & H8 & & H40 & H18 & H8 \\
\hline $\begin{array}{l}\text { Morphological } \\
\text { characters }\end{array}$ & & & & $\begin{array}{l}\text { Fermentation of } \\
\text { sugars }\end{array}$ & & & \\
\hline Gram staining & -ve & $+\mathrm{ve}$ & -ve & Glucose & + & + & + \\
\hline Motility & + & + & + & Sucrose & - & + & + \\
\hline Cell shape & Rod & Rod & Rod & Mannitol & - & + & + \\
\hline Endospore formation & - & + & - & Inositole & - & + & - \\
\hline & & & & Sorbitol & - & + & + \\
\hline Biochemical characters & & & & Rhamnose & - & + & + \\
\hline Enzyme profile & & & & Melibiose & - & + & + \\
\hline$\beta$-galactosidase & - & + & + & Amygdalin & - & + & + \\
\hline Arginine dihydrolase & + & - & + & Arabinose & + & - & + \\
\hline Lysine decarbolase & - & - & - & Starch & - & - & - \\
\hline Orenthinedecarbolase & - & - & + & Citrate utilization & + & - & + \\
\hline Urease & - & - & - & & & & \\
\hline Tryptophane deaminase & + & + & + & Other tests & & & \\
\hline Gelatenase & + & + & + & $\mathrm{H}_{2} \mathrm{~S}$ production & - & - & - \\
\hline Catalase & + & + & + & Acetoin production & - & + & + \\
\hline Amylase & - & - & - & Indole production & - & - & - \\
\hline Lipase & - & - & + & & & & \\
\hline Oxidase & + & - & + & & & & \\
\hline Nitrate reduction & & & & & & & \\
\hline to nitrite- & - & + & - & & & & \\
\hline to $\mathrm{N}_{2}$ gas - & + & - & + & & & & \\
\hline
\end{tabular}

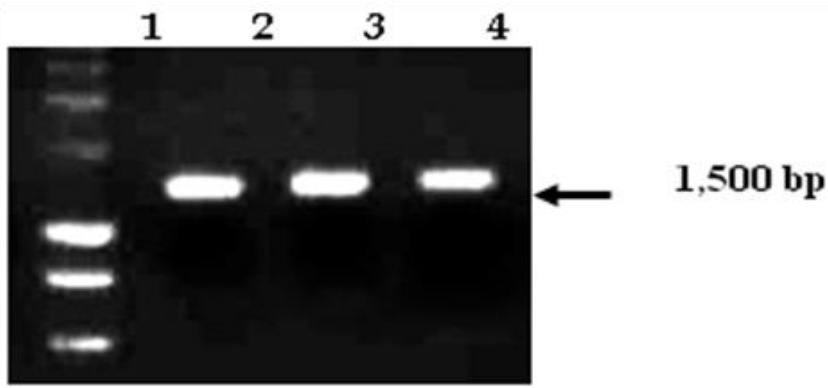

Fig. 2. Gel electrophoresis of PCR products of the $16 \mathrm{~S}$ rDNA gene $(1500 \mathrm{bp})$ of the endophytic bacterial isolates H40 (lane 2), H18 (lane 3), H8 (lane 4) whereas lane (1) contains Hyperladder I.

Egypt. J. Bot., 56, No. 3 (2016) 


\section{Discussion}

Production of extremely diverse bioactive compounds by endophytic bacteria and their potential use as biological control agents has been reported to be dependent on many parameters. Among which are taxonomical position, physiological characters, geological conditions (Sharma et al., 2009). Endophytic bacteria might either become localized at the entry point or spread throughout the plant tissues ( Liu et al., 2015). They can effectively antagonize phytopathogens via releasing various bioactive molecules since both of them reside the same ecological place.

In the present study, different endophytic bacteria were isolated from crop plants in Egypt. These strains were screened in order to find those with strong antagonistic effect against different fungal and bacterial pathogens that cause great losses to crop plants. About half of the bacterial endophytes of this work were isolated from roots of the gathered plants clarifying that most of the endophytic microorganisms exist in the plant roots while their number decreases in stem and leaves as reported by Sharma and Roy (2015). The endophytic bacterial isolates were identified using biochemical characters and the 16S rDNA gene sequence as Pseudomonas aeruginosa, Bacillus subtilis and Stenotrophomonas maltophilia. Many studies showed that the genera Bacillus, Pseudomonas, Agrobacterium and Streptomyces have been considered as main bacteria genera capable of producing antimicrobial active compounds (Raaijmakers et al., 2002; Ongena and Jacques, 2008).

The obtained results revealed that $P$. aeruginosa $\mathrm{H} 40$ has a noticeable antagonistic action in opposition to the majority of the tested phytopathogens. The suppressive impact of $P$. aeruginosa H40 against the fungal and bacterial phytopathogens was attributed to the capability of this strain to produce bioactive molecules that may act as antimicrobial compounds. In agreement with these findings, Shtark et al. (2003) and Reddy et al. (2009) proved the high antifungal activity of presence of pyrrolnitrin identified from $P$. aeruginosa against Rhizoctonia sp., Fusarium sp. In a while, pyrrolnitrin has been used in the development of new phenylpyrrole agricultural fungicides. Besides, additional antibiotics were isolated from $P$. aeruginosa such as pyocyanin $\mathrm{Ib}$, pyocyanin Ic, pyocyanin II, pyocyanin III, phenazines, pyrrolnitrin and pyoluterin (Kumar et al., 2005 and El-Fouly et al., 2015).

Various members of the genus Bacillus are under focus for their broad antagonistic potentiality against wide array of phytopathogenic fungi and bacteria. They release as a minimum 66 diversed antibiotic compounds (Ranjbariyan et al., 2011 and Lin et al., 2009). This study revealed that the bacterial isolate H18 (Bacillus subtillus) that was isolated from pepper stem, verified antimicrobial activity against most of the tested phytopathogens with strong inhibition against $F$. solani, S. rolfsii, $R$. solani, A. solani, and Erwina carotovora. Earlier investigations documented that peptide antibiotics such as 
iturins, mycosubtilins and bacillomycins are the principal class of the active compounds with antimicrobial activities produced by B. subtilis (Ongena and Jacques, 2008; Ali et al., 2014). At the same time, Stenotrophomonas maltophilia that is usually exist in the rhizosphere of cruciferous plants has been found in association with mustard, corn and beet roots (Debette and Blondeau, 1980). This investigation clarified a clear antimicrobial activity of the endophytic bacterial strain $S$. maltophilia $\mathrm{H} 8$ that was isolated from cabbage root against the phytopathogens $R$. solani and $P$. ultimum. In agreement with these results, Berg et al. (1996) recorded that $S$. maltophilia inhibited the growth of $R$. solani, possibly as a result of antibiosis and production of some lytic enzymes.

At the same time, Kai et al. (2007) recorded an apparent reduction of the mycelial growth of $R$. solani exposed to organic volatile compounds of the bacterial culture of $S$. maltophilia R3089. In addition, Pythium ultimum damping-off disease of sugar beet seedling was antagonized by $S$. maltophilia isolated from sugar beet (Dunne et al., 2000). Jakcobi et al. (1996) reported that S. maltophilia R3089 produces an antibiotic called maltophilin that inhibits the growth of several human pathogens in addition to some phytopathogenic fungi. The gained results showed an obvious antibacterial activity of $S$. maltophilia $\mathrm{H} 8$ against the bacterial phytopathogens Erwina carotovora $I$ and Erwina carotovora II. The remarkable antimicrobial activity of the endophytic bacteria S. maltophilia agrees with Messiha et al. (2007) who reported that S. maltophilia can significantly inhibit potato brown rot disease caused by Ralstonia solancrearum in Egyptian clay soil. Furthermore, Elhalag et al. (2016) clarified the efficiency of $S$. maltophilia in controlling the wilt caused by Ralstonia solancrearum. The biocontrol activity of $S$. maltophilia was ascribed to the impact of alkaline serine proteolytic enzyme in addition to the induction of host systemic acquired resistance.

\section{Conclusion}

Endophytic bacteria can release a wide array of extracellular bioactive metabolites with high capability to inhibit the growth of various bacterial and fungal species thus they can be used to manage different plant diseases. The present study revealed that the three endophytic bacterial strains S. maltophilia (H8), B. subtilis (H18) and P. aeruginosa (H40) demonstrated broad spectrum antimicrobial activities against various phytopathogens. Further investigations are recommended to identify metabolites with antifungal and antibacterial activities from endophytic bacteria and to evaluate their antimicrobial effectiveness against various phytopathogens in vivo study.

Acknowledgements : The authors wish to thank Prof. Dr. Refaat M. Ali, Prof. of Plant Physiology, for his great support and valuable suggestions. We also gratefully acknowledge all the staff of the Botany Department, Faculty of Science, Fayoum University.

Egypt. J. Bot., 56, No. 3 (2016) 


\section{References}

Ali, S., Hameed, S., Imran, A., Iqbal, M. and Lazarovits, G. (2014) Genetic, physiological and biochemical characterization of Bacillus sp. strain RMB7 exhibiting plant growth promoting and broad spectrum antifungal activities. Microbial. Cell Fact., 13, 144. DOI 10.1186/s12934-014-0144-x.

Amaresan, N., Jayakumar, V. and Thajuddin, N. (2015) Isolation and characterization of endophytic bacteria associated with chilli (Capsicum annuum) grown in coastal agricultural ecosystem. Indian Journal of Biotechnology, 13 (2), 247-255.

Andrews, J.H. (1992) Biological control in the phyllosphere. Annual Review of Phytopathology, 30, 603-35.

Berg, G., Krechel, A., Ditz, M., Sikora, R.A., Ulrich, A. and Hallmann, J. (2005) Endophytic and ectophytic potato-associated bacterial communities differ in structure and antagonistic function against plant pathogenic fungi. FEMS Microbiol. Ecol., 51, 215-229.

Berg, G., Marten, P. and Ballin, G. (1996) Stenotrophomonas maltophilia in the rhizosphere of oilseed rape occurrence, characterization and interaction with phytopathogenic fungi. Microbiological Research, 151, 19-27.

Bhattacharjee, R. and Dey, U. (2014) An overview of fungal and bacterial biopesticides to control plant pathogens/diseases. Afr. J. Microbiol. Res., 8 (17) 1749-1762.

Chakraborty, U., Chakraborty, B.N. and Chakraborty, A.P. (2010) Influence of Serratia marcescens TRS-1 on growth promotion and induction of resistance in Camellia sinesis against Fomes lamaoensis. J. Plant Int., 5, 261-272.

Cho, K.M., Hong, S.Y. and Lee, S.M. (2007) Endophytic bacterial communities in Ginseng and their antifungal activity against pathogens. Microb. Ecol., 54, 341-351.

Chung, E.J., Hossain, M.T. and Khan, A. (2015) Bacillus oryzicola sp. nov., an endophytic bacterium isolated from the roots of rice with antimicrobial, plant growth promoting, and systemic resistance inducing activities in rice. Plant Pathology Journal 31 (2), 152-164.

Debette, J. and Blondeau, R. (1980) Presence de Pseudomonas maltophilia dans la rhizosphere de quelques plantes culti- vees. Canadian Journal of Microbiology 26, $460-463$.

Dunne, C., Moenne-Loccoz, Y. and Bruijn, F.J. (2000) Overproduction of an inducible extracellular serine protease improves biological control of Pythium ultimum by Stenotrophomonas maltophilia strain W81. Microbiology 146, 2069-78.

Dutta, D., Puzari, K.C. and Gogoi, R. (2014) Endophytes: Exploitation as a tool in plant protection. Braz. Arch. Biol. Technol., Curitiba, 57 (5), 621-629.

El-Fouly, M.Z., Sharaf, A.M., Shahin, A.A.M., El-Bialy, H.A. and Omara, A.M.A. (2015) Biosynthesis of pyocyanin pigment by Pseudomonas aeruginosa. J. Radiation Res. Appl. Sci., 8 (1), 36-48. 
Elhalag, K.M., Messiha, N.A.S., Emara, H.M. and Abdallah, S.A. (2016) Evaluation of antibacterial activity of Stenotrophomonas maltophilia against Ralstonia solanacearum under different application conditions. Accepted manuscript online: 14 FEB 2016 09:48PM EST | DOI: 10.1111/jam.13097.

Essa, A.M. (2012) The effect of a continuous mercury stress on mercury reducing community of some characterized bacterial strains. Afr. J. Microbiol. Res., 6 (6), 1255-1261.

Guo, B., Dai, J. and Huang, N.Y. (2000) Cytonic acids A, and B: Novel tridepside inhibitors of CMV protease from the endophytic fungus Cytonema sp. Journal of Natural Products 63, 602-604.

Hameed, A., Yeh, M.W., Hsieh, Y.T., Chung, W.C., Lo, C.T. and Young, L.S. (2015) Diversity and functional characterization of bacterial endophytes dwelling in various rice (Oryza sativa L.) tissues, and their seed-borne dissemination into rhizosphere under gnotobiotic P-stress. Plant and Soil, 394 (1-2), 177-197.

He, R., Wang, G. and Liu, X. (2010) Antagonistic bioactivity of an endophytic bacterium isolated from Epimedium brevicornu. Afr. J. Biotechnol., 8, 191-195.

Jakcobi, M., Winkelmann, G. and Kaiser, D. (1996) Maltophilin: A new antifungal compound produced by Stenotrophomonas maltophilia R3089. The Journal of Antibiotics, 49, 1101-4.

Kai, M., Effmert, U. and Berg, G. (2007) Volatiles of bacterial antagonists inhibit mycelial growth of the plant pathogen Rhizoctonia solani. Archives of Microbiology 187, 351-60.

Kumar, R.S., Ayyadurai, N. and Pandiaraja, P. (2005) Characterization of antifungal metabolite produced by a new strain Pseudomonas aeruginosa PUPa3 that exhibits broad-spectrum antifungal activity and biofertilizing traits. J. Appl. Microbiol., 98, $145-54$.

Lin, L., Qiao, Y.S. and Ju, Z.Y. (2009) Isolation and characterization of endophytic Bacillius subtilis antagonist of eggplant Verticillium Wilt. Bioscience, Biotechnology \& Biochemistry, 73, 1489-1493.

Liu, Y., Li, Y., Yao, S. and Wang, H. (2015) Diversity and distribution of endophytic bacterial community in the Noni (Morinda citrifolia L.) plant. Afr. J. Microbiol. Res., 9 (25), 1649-1657.

Messiha, N.A.S., Van Diepeningen, A. and Farag, N.S. (2007) Stenotrophomonas maltophilia : a new potential biocontrol agent of Ralstonia solanacearum , Causal Agent of Potato Brown Rot , 211-225.

Ongena, M. and Jacques, P. (2008) Bacillus lipopeptides: versatile weapons for plant disease biocontrol. Trends In Microbiology , 16, 115-25.

Prescott, L.M., Harley, J.P. and Klein D.A. (1996) "Microbiology". Wm. C. Brown Publishers, England, 390 pp.

Egypt. J. Bot., 56, No. 3 (2016) 
Qiao, H., Huang, L. and Kang, Z. (2006) Endophytic bacteria isolated from wheat and their antifungal activities to soil-borne disease pathogens. J. Appl. Ecol., 17, 690-4.

Raaijmakers, J.M., Vlami, M. and de Souza, J.T. (2002) Antibiotic production by bacterial biocontrol agents. Antonie van Leeuwenhoek, 81, 537-547.

Ranjbariyan, A., Shams-Ghahfarokhi, M., Kalantari, S. (2011) Molecular identification of antagonistic bacteria from Tehran soils and evaluation of their inhibitory activities toward pathogenic fungi. Iran. J. Microbiol., 3, 140-6.

Reddy, B., Reddy, M. and Kumar, K. (2009) Characterization of antifungal metabolites of Pseudomonas fluorescens and their effect on mycelial growth of Magnaporthe grisea and Rhizoctonia solani. Int. J. Pharm. Technol Res., 1, 1490-1493.

Rosenblueth, M. and Martínez-Romero, E. (2006) Bacterial endophytes and their interactions with hosts. Molecular Plant-Microbe Interactions 19 (8), 827-837.

Sabuquillo, P., Cal, A. and Melgarejo, P. (2006) Biocontrol of tomato wilt by Penicillium oxalicum formulations in different crop conditions. Biological Control, 37, 256-265.

Schulz, B. and Boyle, C. (2006) "What are Endophytes? Microbial Root Endophytes". Springer Berlin Heidelberg, Berlin, Heidelberg, 1-13.

Seo, W.T., Lim, W.J. and Kim, E.J. (2010) Endophytic bacterial diversity in the young radish and their antimicrobial activity against Pathogens. J. Korean Soc. Appl. Biol. Chem., 53, 493-503.

Sharma, R.R., Singh, D. and Singh, R. (2009) Biological control of postharvest diseases of fruits and vegetables by microbial antagonists. Biological Control, 50, 205-221.

Sharma, S. and Roy, S. (2015) Isolation and Identification of a novel Endophyte from a plant Amaranthus spinosus. Int. J. Curr. Microbiol. App. Sci., 4 (2), 785-798.

Shi, Y., Zhang, X. and Lou, K. (2013) Isolation, characterization and insecticidal activity of an endophyte of drunken horse grass, Achnatherum inebrians. Journal of Insect Science, 13 (151), 1-12.

Shtark, Oi., Shaposhnikov, A. and Kravchenko, L. (2003) The production of antifungal metabolites by Pseudomonas chlororaphis grown on different nutrient sources. Mikrobiologia, 72, 645-50.

Soutourina, O.A., Semenova, E.A., Parfenova, V.V., Danchin, A. and Bertin, P. (2001) Control of bacterial motility by environmental factors in polarly flagellated and peritrichous bacteria isolated from Lake Baikal. Appl Environ Microbiol, 67, 3852-3859.

Suryanarayanan, T.S., Wittlinger, S.K. and Faeth, S.H. (2005) Endophytic fungi associated with cacti in Arizona. Mycological Research, 109, 635-9. 
ان البكتيريا المعزولة من داخل النباتات قد لاقت الكثير من الاهتمام فى الفترة

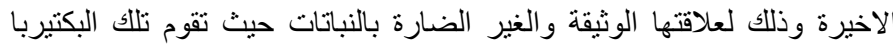

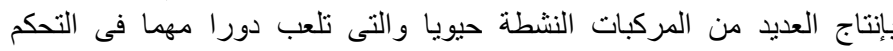

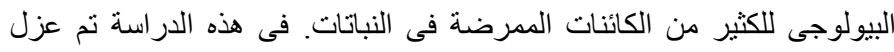

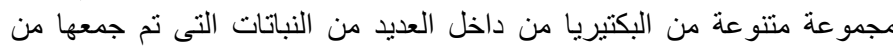

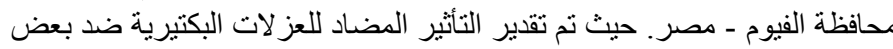
الكائنات الممرضة للنبات. تم تسجيل نشاط قوم مضاد للفير الفريات للعزلة للة البكتيرية

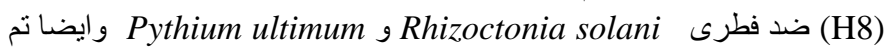

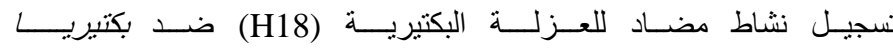
Erwinia carotovora و Erwinia carotovora فقد أظهرت نشاط بارز مثبط ضد بكتيريا (H40)

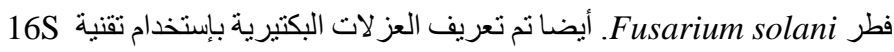
Bacillus Stenotrophomonas maltophilia كالأتى subtilis - Pseudomonas aeruginosa يمكن استخدام هذه العزلات البكتيرية كعوامل للتحكم البيولوجى فى العي العديد من

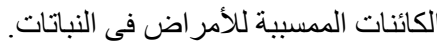

